\title{
Empirical evidence on Non-Performing Loans and credit frictions: banking sector in Tunisia
}

\author{
Salha Ben Salem ${ }^{1}$, Moez Labidi², Nadia Mansour ${ }^{3}$
}

University of Monastir, Tunisia ${ }^{1,2}$

University of Sousse, Tunisia \& University of Salamanca, Spain ${ }^{3}$

mansour.nadia@hotmail.com

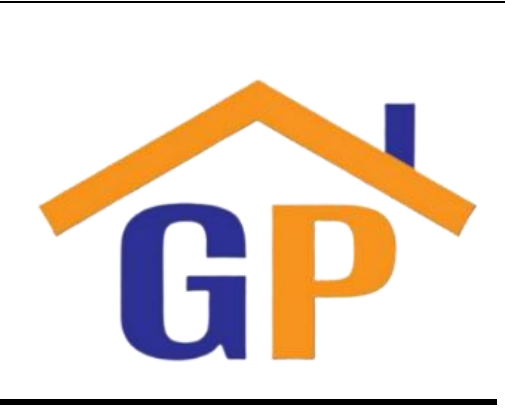

Article History

Received on 8 July 2020

$1^{\text {st }}$ Revision on 17 July 2020

$2^{\text {nd }}$ Revision on 18 August 2020

$3^{\text {rd }}$ Revision on 19 August 2020

Accepted on 21 August 2020

\begin{abstract}
Purpose: This paper explores the most important determinants of friction in the Tunisian credit market. The previous literature argued that friction is largely explained by the increase in Non-Performing Loans Nkusu, 2011; Abadi et al., 2014; Rulyasri et al., 2017; Roland et al, 2013 .
\end{abstract}

Research methodology: We constructed a multivariate Vector Error Correction Model, with five macroeconomic variables (industrial production index, the money supply, money market interest rate) to examine the impact of Non-Performing Loans increase in amplifying the Tunisian credit frictions.

Results: The Vector Error Correction Model (VECM) regression results show a negative and important relationship between economic growth and Non-Performing Loans (NPL) ratio, which is very robust during the political crisis of 2011. The money market interest rate and the money supply are positively related to the NonPerforming loan ratio.

Limitation: This study was only focused on Tunisian banking sector as one of the pillars of the Tunisian economy.

Contributions: This highlights that the nature of the monetary policy adopted by the monetary authority of Tunisia plays a significant role in the fluctuation of the Non-Performing Loans ratio. Bank capitalization is positively and statistically significant with Non-Performing Loan ratio, implying that banks with a low level of capital are more likely to have a riskier credit portfolio that causes the increase of Non-Performing Loans in their balance sheet.

Keywords: Non-Performing Loans, Credit friction, Macroeconomic factor, Vector error correction model, Tunisian banking sector

JEL classification: G21, G210, G44

How to cite: Salem, S. B., Labidi, M., \& Mansour, N. (2020). Empirical evidence on Non-Performing Loans and credit frictions: banking sector in Tunisia. International Journal of Financial, Accounting, and Management, 2(3), 171-183.

\section{Introduction}

The increase of ex-post loan risk is considered as one of the essential problems in the banking sector. More specifically, the ex-post loan risk appears as Non-Performing Loans. The rise in NPL leads economists to investigate the effect of macroeconomic shocks on credit friction and financial instability. Currently, the increase of Non-Performing Loans stock is heavily weighing on the profitability of Tunisian banks and continuing to present risks for real and financial stability (Bouzgarrou and Béjaoui,

\footnotetext{
${ }^{1}$ salha.bensalembannour@gmail.com

2 moezlabidi@gmail.com

${ }^{3}$ Corresponding author: Nadia Mansour (mansournadia@usal.es)
} 
2013). The massive supply of credit, especially by public banks, resulted a very high level of NPL ratio ${ }^{4}$, stood at 14.6\% in December 2018 against 13.5\% in 2017 and 12\% in 2012. This situation prompted the Central Bank of Tunisia to implement important legal and administrative reforms, especially political crisis of 2011, to counter this increase and rationalize insolvency procedures.

Among many papers analyzing the NPL problems, this paper aims to treat the macroeconomic determinants that explain the degradation of loan portfolio quality in the Tunisian system bank. This study is a major novelty since we applied this econometric method for the first time on Tunisia. In this direction, the explanatory power of macroeconomic indicators will be analyzed. Furthermore, we examine the feedback effect of NPLs on the real economy, which is related to the real or non-financial elements of an economy. Following Abadi et al. (2014), we employ the Johansen Cointegration test to examine the long-run relationships among our system variables and the VECM regression to study the causal relationships and select key determinants of NPL and then we use the variance decomposition technique to highlight the importance of each key determinant of NPL.

The rest of this paper is presented as follows: Section 2 presents the literature review on the determinants of NPL, namely macroeconomic indicators, and the feedback effect of loan quality on the real economy. Section 3 describe the main characterizing of the Tunisian sector bank. Section 4 includes the methodology and data. Section 5 is dedicated to empirical findings. Finally, the last section wraps everything up with a conclusion and policy implications.

\section{Literature review and hypothesis development}

Economic studies conclude that the quality of assets is a considerable statistical variable of the bankruptcy signals (Barr and Siems, 1994; Khemraj and Pasha, 2009; Smaranda, 2017; Charalambakis \& Garrett, 2019). For this reason, the issue of non-performing loan factor has occupied the attention of several researchers and brought their attention to determine the variables leading to financial frictions. For instance, Sorge (2004) introduced Non-Performing Loans and loan losses provisions variables to evaluate the friction in the financial market.

Using an example of 26 advanced economies, Nkusu (2011) shows that several macroeconomic variables such as a fall in real GDP, a higher unemployment rate, an increase in the interest rates, a reduction of house prices and deterioration of equity prices are related with the higher level of NPL. Adebola et al. (2011) introduce new variables that had better explain the credit risk in the Malaysian banking system from 2007 to 2009. They use "the Auto-Regressive Distributed Lag (ARDL)" model to analyze the respective impacts of some macroeconomic factors such as the industrial production index, the interest rate, and the producer price index. Their results confirm the existence of "long-term relationships" between variables and show that the interest rate has a significant positive long-term effect on credit risk. The producer price index seems to have a negative and significant effect on credit risk.

In their research on credit risk, Buncic and Melecky (2012) \& Surjaningsih et al. (2018) estimated the elasticity of NPLs to four key macroeconomic variables in 54 high- and medium-income countries. They found that the NPL is negatively linked to the growth rate of GDP and positively to the real interest rate and unemployment rate. Their results corroborate those of Messai and Jouini (2013) who used a sample of 85 banks in three countries (Italy, Greece, and Spain) during the period of 2004-2008. Beck et al. (2013) exploit a more complete set of macroeconomic variables. They conclude that the increase in NPL ratio is associated with an increase in the lending rate and a reduction in asset prices, while the decrease in this ratio leads to a significant fall of the unemployment rate.

According to Abidi et al. (2015), there is strong evidence that the loan quality in the Tunisian banking is sensitive to the economic cycle. Using a dynamic panel model, they conclude that the macroeconomic factors, such as economic growth, inflation level and microeconomic factors, such as the quality of management, play an important role in the increase of households' non-performing loan in Tunisia. Meanwhile, the study of Ouhibi et al. (2017) shows a positive and significant association between the

\footnotetext{
${ }^{4}$ Defined as the report of non-refund credits and the total credit granted by banks. 2020 | International Journal of Financial, Accounting, and Management/ Vol 2 No 3, 171-183 
unemployment rate, inflation, domestic credit to the private sector and NPLs, while GDP and gross capital formation have a negative effect on NPLs.

Since the NPLs are indicators of bank profitability, BIS (2017), some survey attempt to associate NPLs with financial development. One survey, Ozili (2019), use a panel data for 134 countries from 2003 to 2014. Their findings show that financial development, such as bank profitability, banking system stability, is negatively linked with NPLs while banking crises and bank competition are positively linked with NPLs. Moreover, in a regional survey, Ozili show that NPLs are negatively related to bank capitalization and bank liquidity, meaning that banking sectors with higher capital level and liquidity have fewer NPLs.

The literature presents also significant evidence on the feedback impact of NPLs on the real activity. The literature shows that the retroactive effect of the credit risk and economic activity can be summed in three primary channels: interest rate, balance sheet, and securitization channels (see figure 1 underneath). Without a doubt, a high level of Non-Performing Loans pushes banks to expand their lending interest rates, which increases the credit spread. This amplification makes the credits very expensive and attract, therefore, risky borrowers and raise the debt service. This mechanism increments again the weight of NPLs in the bank's balance sheet. The second channel (balance sheet channel) traces the amplifying effect of NPL on the credit supply and bank efficiency. The growth of NPL increases the need of banks for liquidity and tighten the credit supply conditions. The third channel is emphasized by Fell et al. (2016) who consider that the information asymmetry characterizing the financial market expands the spread between the price of a loan portfolio offered by the bank and the value that investors are happy to pay. This defect forces the banks to support extra costs to persuade the investors which thusly brings the reduction of their profitability.

Figure 1 : NPLs and credit friction: retroactive effects

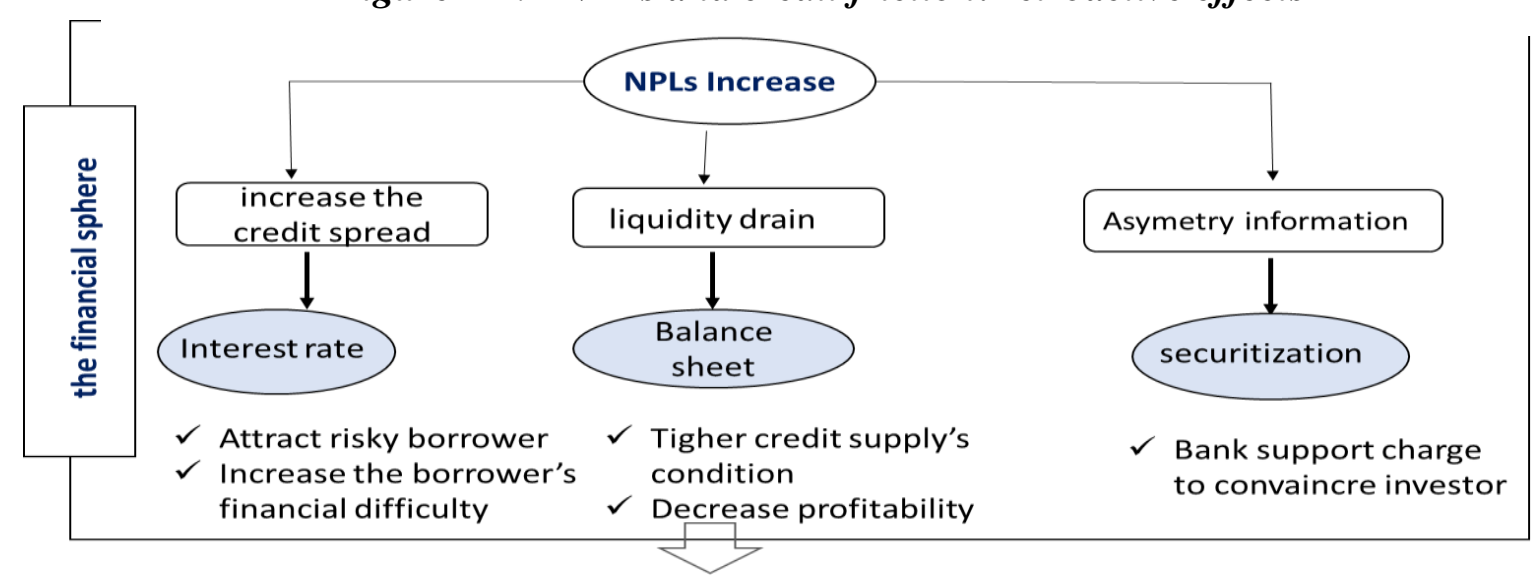

Credit Crunch

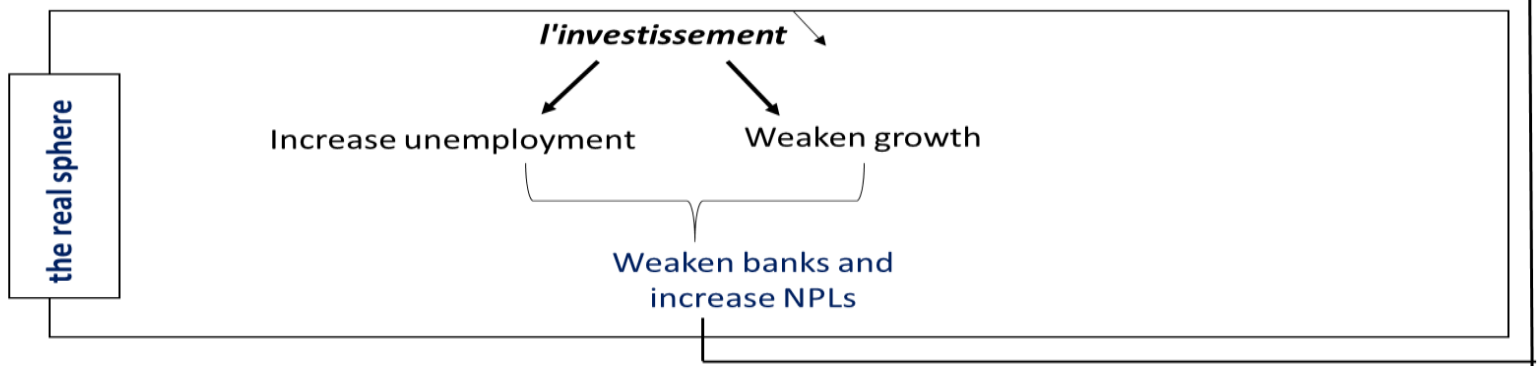

Source: prepared by Authors

A high level of NPL affects not only the financial market but also the real economy through the reduction of investment and the increase of the unemployment rate, which in turn questions the effectiveness of monetary policy. Nkusu (2011) shows that an overall increase in bad debt leads to a continued deterioration of macroeconomic variables during the four years following the initial shock. 
The reaction of the real GDP and the unemployment rate prove the complementarity between the banking sector and the conjuncture of the economic activity.

These findings are supported by De Bock and Demyanets (2012), who study the vulnerability of economic activity in the emerging countries in case of macroeconomic shocks. Based on a SVAR model, De Bock and Demyanets (2012) shed light on a significant relationship between bank asset quality, credit growth and macroeconomic aggregates. Additionally, they show that the reduction in GDP growth rate intensifies the credit frictions, either by the increase of payment's default or by the contraction of credit's supply.

\section{Tunisian banking system and Systematic root of non-performing loan}

The financial intermediation in Tunisia is generally youthful. Founded in the aftermath of independence in 1956, it is during the recent 30 years that its major transformations took place. The banking sector has an essential impact on the economy. Indeed, it contributes to the acceleration of economic growth while intervening in the financing of various sectors of activity such as construction and public works, agriculture, communication, transport, tourism, catering, etc. It is all banks and financial institutions as well as the central bank that carry out claims and transactions between themselves and vis-à-vis nonfinancial agents. Each country has its own financial system.

Today, the market has 29 establishments, including 11 intermediation system. The Tunisian banking sector compromises 30 banks, 23 of which are resident, and 7 non-residents. Three of these banks are state-owned: STB, BNA, and BH. It likewise incorporates 13 financial institutions including 8 leasing institutions, 3 factoring firms, and 2 investment banks. Resident banks hold over $90 \%$ of the credits, assets, and deposits of every financial institution (Tanitjobs, 2019).

As a reminder, Tunisia is one of the first countries that implemented financial reforms in the MENA region in North Africa. Until before the 1980s, this sector was subject to strict control. After that, it went through a period of progressive reforms but which has not yet allowed the sector to flourish. Stateowned banks are still dominant and manage half of the market. However, this hurts economic growth because the State controls the market. State banks hold shares in public structures. They grant them loans but this does not allow them to allocate savings to the most interesting investments. This leads to a rise in financing rates which are not performing well in the past years. It should be noted that there are 2 investment banks, 8 offshore banks, factoring, and leasing companies among Tunisian banks. The financial network also extends to the Financial Market Council, the Tunis Stock Exchange to name but a few. There are currently 1430 bank branches in the country, owes one branch for 7,700 people.

Tunisia's financial intermediation is somewhat specific as for its "atomicity" property (between universal private banks, particular banks, public banks, investment banks...). A better grouping of the banking sector would be, today, much more desirable for the solidness of the financial market. With a market capitalization reach 8 billion TND; the financial intermediation is the principal power in the market, accounting for $41 \%$ of aggregate capitalization. Its health state basic indicator of the stock market investment.

Today, nine years after the revolution, the opportunity has arrived, and the beginning of recovery seems to be emerging. This sector has three public banks (Tunisian Society of Banks ${ }^{5}$, National Agricultural Bank, Housing Bank,), they capture 38\% of banking assets, as much as their future is essential to our economic system. However, the health state of these banks is less reassuring. Between 2010 and 2015, customer deposits increased by only $23 \%$, compared to $47 \%$ at Tunisia's top three private banks. Outstanding customer loans increased by $20 \%$ over the same period, compared with $58 \%$ for their private competitors. The results of the Banque Internationale Arabe de Tunisie (BIAT), the country's leading bank, alone exceed those of the three major public banks combined.

\footnotetext{
${ }^{5}$ STB, BNA and BH stand for "Société Tunisienne de Banque", Banque Nationale Agricole" and "Banque de l'Habitat", respectively 2020 | International Journal of Financial, Accounting, and Management/ Vol 2 No 3, 171-183 
In a context of a very aggressive competitive environment and a public governance showing signs of weaknesses, the public sector needs, jointly with its recapitalization, a complete overhaul of its mode of governance.

The Tunisian banking sector suffers from several shortcomings caused mainly by the previous regime damage and by the weakness of the national economy after the revolution, which helps to paralyze its ability to raise funds for productive projects. Thereby, this sector, characterized by a misallocation of resources, contributes to the weak performance of the Tunisian economy.

Despite the significant weight of the banking sector in the economy finance, the domestic loan to the GDP remains relatively low compared to other neighboring countries. For example, in 2017, this ratio amounts to $108.3 \%$ in Morocco to $203 \%$ in Lebanon, while in Tunisia it is $92.85 \%$, against $74.48 \%$ in 2010, according to the World Bank.

\section{Figure 2: Total domestic credit of GDP}

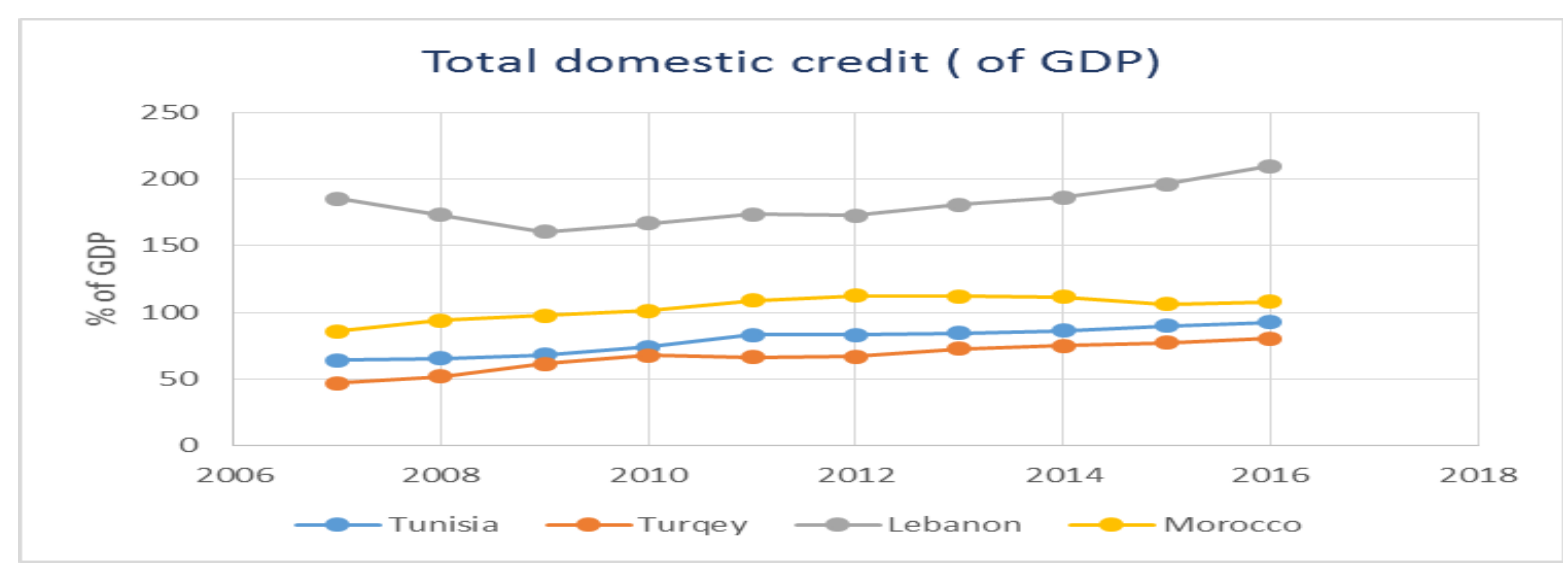

Source: IMF annual report 2017

This sector was very affected by the revolution of January 2011, which led to the accumulation of a large stock of Non-Performing Loans. Indeed, concerned with their profitability, banks increase their interest margins; leading to a greater likelihood of counterparty default and limiting the ability of borrowers to repay debt service. Currently, the Tunisian banking sector suffers from a very important level of Non-Performing Loans, mostly in public banks, reaching $15.6 \%$ in 2016 . The main causes of this alarming ratio are; the poor quality of portfolio and risk management in the Tunisian banking sector (ROA and ROE represent $0.9 \%$ and $10.9 \%$, respectively in 2016) and the strong competition in the market. The latter factors increase the catch of risk by banks, political instability and low growth rate, etc.

If we compare the NPL ratio of Tunisia to that of other neighboring countries, we can conclude that this ratio is a real threat towards the credit friction in the Tunisian bank, see figure below:

Figure 3: NPLs to gross loans

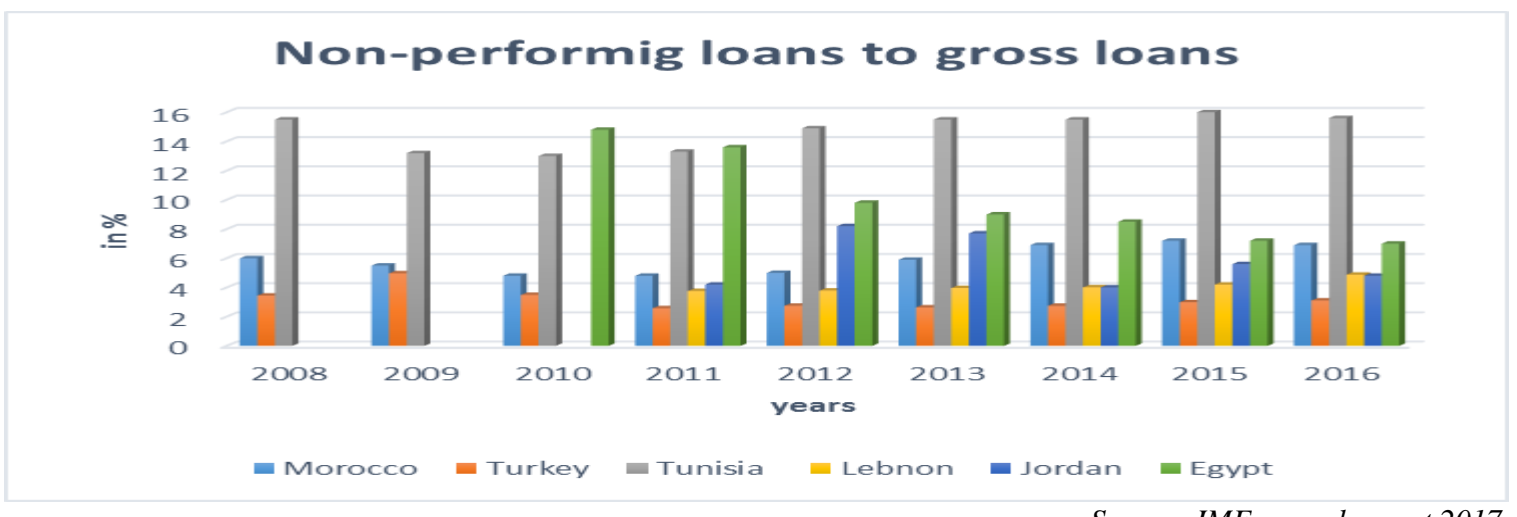

Source: IMF annual report 2017 
According to figure 3, we note that, since 2010, Tunisia is characterized by the presence of credit friction mainly caused by the non-performing loan rise, whereas Turkey has the lowest ratio compared to the other countries.

In order to struggle against these toxic assets, the monetary authority recapitalizes three public banks, namely STB, BNA and BH. The amount of the recapitalization costs one percent of GDP. The results of the audit of $\mathrm{BH}$ are not yet available. This percentage reflects the budgetary cost borne by the government because of the persistent vulnerabilities of public banks. This cost would increase if the sources of these vulnerabilities were not seriously considered. Lack of efforts to monitor the emergency of NPL led to the decrease of the solvency ratio of the banking sector from $12.2 \%$ in 2015 to $10 \%$ at the end of 2016, but it remains largely lower than that required by international standards.

The increase of NPLs and losses supported by intermediate system on its loan portfolios highlighted the importance to analyze the determinants of credit friction in order to protect this imperfection and ensure real and financial stability (Hassad and El chak, 2010).

\section{Research methodology}

This paper aims to treat the macroeconomic indicators that explain the degradation of loan portfolio quality in the Tunisian system bank. We follow the recent literature in non-performing loan such as Abadi et al., 2014, Rulyasri et al., 2017.

\subsection{Data description}

Data in this research includes five monthly data from January 2000 to February 2018, (see table 1 for the complete list of variables). This data set is collected from the Tunisian National Institute of Statistics (INS) and the website of the Tunisian Central Bank ${ }^{6}$. The database is subdivided into two subsets: the first includes financial variables such as the NPL ratio (RNPL), total credit (loan) and bank capital (CAP). The second group includes macroeconomic variables which were shown to have a strong influence on NPLs such industrial production index(IPI), as a proxy of economic activity, money supply (M2) and money market interest rate (TMM).

In what follows, we provide a detailed explanation of considered set of variables:

-RNPL: the non-performing credit ratio. It presents one of the main ratios measuring imperfection in Tunisian banks. It implies that the higher the non-performing ratio is, the lower profitability the bank will have. For this reason, we adjust the NPL ratio as a measure of friction in the credit market, as it reduces the ability of banks to satisfy the credit demands of their borrowers.

-CAP: is the level of bank capitalization. These funds represent the main tool for which the bank decides to supply credits, especially in countries where the financial market is not very developed and the majorities of the companies are of small and average size. CAP is anticipated to have a significant negative impact on RNPL, which implies that the banks with a low level of capital is likely to take more risk in their credit portfolio as argued by Meh (2011), $\underline{\operatorname{Mimir}(2013)}$ and Hue (2015) for example.

-Loan: measures the total amount of credits offered by Tunisian banks. The expected sign of the loading parameter associated to RNPL variable is positive, which implies that the growth in credit supply leads to the rise of the NPL.

-IPI: This index reflects the global economic activity. It is used to analyze the impact of the economy growth on the dynamics of NPL ratio. Econometric modeling confirms an adverse and significant relationship between IPI and RNPL: the reduction in industrial activity widens the financial situation of the contractor, which increases its non-payment probability.

\footnotetext{
${ }^{6}$ www.bct.gov.tn

2020 | International Journal of Financial, Accounting, and Management/ Vol 2 No 3, 171-183 
-TMM: This variable is introduced in order to detect the reaction of the Central Bank of Tunisian following the increase in Non-Performing Loans.

-M2: We assume that the relationship between M2 and RNPL is positive. The increase of liquidity pushes banks to grant more credits which increase the likelihood of NPL.

Table 1: Definition and expected respective signs of the financial and macroeconomic variables

\begin{tabular}{|c|c|c|c|}
\hline Variable & Definition & $\begin{array}{l}\text { Expected signed with } \\
\text { credit friction }\end{array}$ & Literature \\
\hline RNPL & $\begin{array}{l}\text { RNPL } \\
=\frac{\text { non performing loan }}{\text { total loan }}\end{array}$ & $(+)$ & $\begin{array}{l}\text { Hassad and El chak (2010), } \\
\text { Ouhibi and al. (2017) }\end{array}$ \\
\hline Loan & total credits & $(+)$ & $\begin{array}{c}\text { Nukusu (2011), De Bock and } \\
\text { Demyanets (2012), Erdoğdu, } \\
\text { (2015) }\end{array}$ \\
\hline CAP & bank capitalization & $(-)$ & $\begin{array}{c}\text { Fawad and Taqadus (2013), } \\
\text { Mimir(2013) }\end{array}$ \\
\hline IPI & industrial production index & $(-)$ & $\begin{array}{l}\text { Espinoza and Prasad (2010), } \\
\text { Messai and Jouini (2013) }\end{array}$ \\
\hline M2 & The money supply & $(+)$ & $\begin{array}{l}\text { Messai and Jouini (2013), } \\
\text { Rulyasri et al. (2017). }\end{array}$ \\
\hline TMM & money market interest rate & $(+)$ & $\begin{array}{l}\text { Adebola et al. (2011), Abidi et } \\
\text { al. (2015), Ekanayake and } \\
\text { Azeez (2016) }\end{array}$ \\
\hline
\end{tabular}

We analyze the sources of credit friction in the Tunisia credit market using "the Vector Error Correction Model (VECM)" techniques. This model is presented as follows:

$$
\Delta \mathrm{y}_{\mathrm{t}}=\rho_{0}+\Pi \mathrm{y}_{\mathrm{t}-\mathrm{i}}+\sum_{\mathrm{i}=1}^{\mathrm{p}} \tau_{\mathrm{i}} \Delta \mathrm{y}_{\mathrm{t}-\mathrm{i}}+\varepsilon_{\mathrm{t}}
$$

where:

$\mathrm{y}_{\mathrm{t}}$ : Vector of endogenous variables of size $(\mathrm{n} \times 1)$, including RNPL and macroeconomics factor

$\rho_{0}$ : Vector of constant of length $\mathrm{n}$.

П: Are square matrices of order $n$.

$\Pi=\alpha \beta^{\prime}$, where $\beta^{\prime}$

$\alpha_{(\mathrm{n} * \mathrm{r})}$ : Contains the speed of adjustment parameters with $r<\mathrm{n}$, and $\operatorname{Rank}(\Pi)=\operatorname{Rank}\left(\alpha \times \beta^{\prime}\right)=r$

$\tau_{\mathrm{i}}$ Regression coefficients at lag $\mathrm{i}$.

\section{Results and discussions}

\subsection{Stationary test}

In accordance with several methods to estimate a VECM model, the first step is to ensure that all variables embodied in the model are stationary at the first difference (Enders, 2004). Using the Augmented Dickey-Fuller (ADF) test and Phillips-Peron (PP) test, we find that all variables are stationary at the first difference and hence are I(1) as required by "the Johansen cointegration test" and VECM modeling. 
Table 2: Results of unit root tests

\begin{tabular}{|c|l|l|l|l|l|}
\hline Variable & $\begin{array}{l}\text { Model } \\
\text { specification }\end{array}$ & ADF test & PP test & ADF test & PP test \\
\hline \multirow{3}{*}{ RNPL $_{\mathrm{t}}$} & Levels & Levels & $\begin{array}{l}\text { First } \\
\text { difference }\end{array}$ & First difference \\
\cline { 2 - 6 } & Intercept & -1.284 & -1.862 & $-2.907^{* *}$ & $-16.436^{* *}$ \\
\cline { 2 - 6 } & $\begin{array}{l}\text { Trend and } \\
\text { intercept }\end{array}$ & -2.931 & -1.698 & $-2.651^{*}$ & $-16.447^{* *}$ \\
\hline \multirow{2}{*}{ Loan $_{\mathrm{t}}$} & Intercept & -1.136 & -1.411 & $-6.543^{*}$ & $-11.352^{* *}$ \\
\cline { 2 - 6 } & $\begin{array}{l}\text { Trend and } \\
\text { intercept }\end{array}$ & -1.618 & -1.563 & $-6.616^{*}$ & $-11.454^{* *}$ \\
\hline \multirow{2}{*}{ IPI $_{\mathrm{t}}$} & Intercept & -1.706 & -3.923 & $-6.539^{* *}$ & $-51.755^{* *}$ \\
\cline { 2 - 6 } & $\begin{array}{l}\text { Trend and } \\
\text { intercept }\end{array}$ & -0.495 & -8.962 & $-6.775^{* *}$ & $-72.057^{* *}$ \\
\hline \multirow{2}{*}{ M2 $_{\mathrm{t}}$} & Intercept & -1.258 & -1.442 & -2.734 & $-15.687^{* *}$ \\
\cline { 2 - 6 } & $\begin{array}{l}\text { Trend and } \\
\text { intercept }\end{array}$ & -0.823 & -0.506 & -12.435 & $-15.964^{* *}$ \\
\hline \multirow{2}{*}{$\mathrm{TMM}_{\mathrm{t}}$} & Intercept & -1.881 & -1.761 & $-7.737^{* *}$ & $-12.456^{* *}$ \\
\cline { 2 - 6 } & $\begin{array}{l}\text { Trend and } \\
\text { intercept }\end{array}$ & -2.573 & -2.405 & -12.143 & $-12.434^{* *}$ \\
\hline
\end{tabular}

Note: $* *$ and $*$ show the reject of the null hypothesis at $5 \%$ and $10 \%$ respectively

After checking the order of integration of system variables, we use the information criteria such as Schwarz Information Criterion (SIC), Test Statistics (LR), Final Forecast Error (FPE), Akaike Information Criterion (AIC), Hannan Quinn Information (HQ) to select the optimal lag order of VECM model. Results of information criteria are reported in Table 3.

Table 3: Optimal lag selection

\begin{tabular}{lllllll}
\hline Lag & LogL & LR & FPE & AIC & SC & HQ \\
\hline \hline $\mathbf{1}$ & 2111.111 & 3657.18 & $2.73 \mathrm{r}-17$ & -21.113 & $-20.4109^{*}$ & $-20.8289^{*}$ \\
\hline $\mathbf{2}$ & 2145.716 & 64.6204 & $277 \mathrm{e}-17$ & -21.099 & -19.794 & -20.5710 \\
\hline $\mathbf{3}$ & 2187.166 & 74.863 & $2.63 \mathrm{e}-17$ & -21.154 & -19.248 & -20.382 \\
\hline $\mathbf{4}$ & 2217.777 & 53.412 & $2.79 \mathrm{e}-17$ & -21.0997 & -18.5910 & -20.0840 \\
$\mathbf{5}$ & 2247.002 & 49.2054 & $3.01 \mathrm{r}-17$ & -21.0306 & -17.9176 & -19.7712 \\
$\mathbf{6}$ & 2303.842 & $92.2203^{*}$ & $2.46 \mathrm{r}-17 *$ & $-21.2432^{*}$ & -17.530 & -19.740 \\
\hline \hline
\end{tabular}

*Indicate lag order selection by the criterion

Results in Table 3 allow selecting 6 as the optimal order of explanatory variables in the VECM system. This confirms that on these lags, there is no problem of autocorrelation, and therefore, the long-term stability is obtained within the sixth period of lag.

\subsection{Johansen Co-integration test}

We now turn to the analysis of the presence of Cointegrating relationships between the variables by applying the Johansen co-integration test. Cointegration relationships indicate whether the variables are connected in the long term and consequently they converge to a common long-run equilibrium.

Table 4: Results of "Johansen cointegration test"

\begin{tabular}{|c|c|c|c|c|}
\hline Eigenvalue & Tace statistic & $\begin{array}{l}5 \% \text { critical } \\
\text { value }\end{array}$ & p-value & $\begin{array}{l}\text { Hypothesized } \\
\text { No. of CE (s) }\end{array}$ \\
\hline 0.1816 & 115.073 & 95.75366 & 0.0012 & None* \\
\hline 0.1655 & 75.1888 & 96.8188 & 0.0175 & At most $1^{*}$ \\
\hline 0.0948 & 39.1698 & 47.85612 & 0.2536 & At most 2 \\
\hline
\end{tabular}

*Means the reject of the null hypothesis at 5\% significance level 
Results of the Johansen cointegration test reported in Table 3 show the presence of one cointegrating relationship between variables, which confirms the suitability of the VECM in our setting.

\subsection{Granger causality test}

We perform the Granger (1969) causality test to detect for the direction of the causalities among our set of variables. Results of the Granger causality test are reported in figure 4.

Figure 4: Results of the Granger causality test

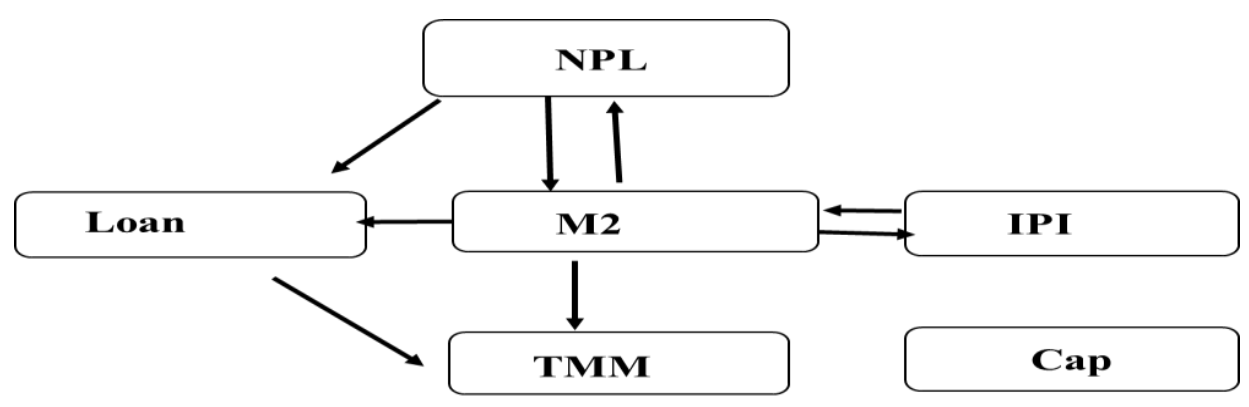

Based on the causality test, there is relationship feedback effect between RNPL and M2 and between IPI and M2. Meanwhile, the RNPL has one-way relationship with loan

\section{Long Run Model}

The existence of cointegration among the variables implies that a VECM model can be estimated in order to undertake analysis of variables relationships in the long-run. The results of the long run estimations are displayed below:

$\mathrm{NPL}=1.036-0.006 \mathrm{IPI}+0.005 \mathrm{TMM}-0.178 \mathrm{Cap}+0.222 \mathrm{M} 2$

(t-statistics)

\section{R-square 0.5836}

\section{F- Statistic 4.076}

Quite consistent with the theory, the results show that IPI has a negative impact against NPL variation during research period with a loading coefficient of 0.006 . This means, a $1 \%$ increase of IPI leads to $0.006 \%$ decrease of NPL by. This result corroborates that of Akinlo and Emmanuel (2014) who found that the economic growth as measure by real GDP growth has a negative influence on NPL in the long run. This finding is also confirmed by Messai and Jounini (2013) using 85 banks in Italy, Greece, and Spain. The recession of the economy as proxied either by GDP or by IPI from each industry, rather of other factors like bank capital and money supply, is the key driver of NPL fluctuations. Skarica (2014) stresses that a recession of the economy reveals a depression of the business performance. It affects the debtor's financial capacity increasing the probability of default that generates the problematic loans. In our context, during the revolution of 2011, this negative relationship is well manifested as the economic activity was seriously affected by the events that Tunisia experienced. As a result, the slowdown in economic activity in the country has led to an increase in Non-Performing Loans by non-financial economic agents.

As regards the interest rate variable, TMM, results show a positive relationship with the NonPerforming Loans ratio (0.005). In fact, when a bank increases its interest rates, it can immediately generate the rise in Non-Performing Loans, particularly, for loans with floating interest rate. This relationship can also be explained by the decrease in the capacity of borrowers to respect their obligations. This is confirmed by the previous researches such as Adebola et al. (2011), Abidi et al. (2015), Ekanayake and Azeez (2015).

Furthermore, the results show a negative and significant relationship between the bank capitalization and the RNPL ratio, which implies that the bank with a low level of capital tends to take 
more risk in their credit portfolio which causes the increase of Non-Performing Loans in their balance sheet. This result is confirmed by the conclusions of Meh (2011), Mimir (2013) and Hue (2015).

The money supply (M2) has a positive (0.222) and significant influence on RNPL over the considered period. This result is explained by the fact that the rise of M2 leads to the increase of goods prices which, further, causes the rise of operational expense and the fall the consumer's demand. This mechanism can impact the financial ability of the business actors, which in turn, affects their performance to repay their commitments at the due date (Messai and Jouini, 2013; Rulyasri et al., 2017).

\subsection{Forecast errors and variance decomposition}

The variance decomposition table shows that bank capitalization and the nature of the monetary policy adopted by the central bank present the main variables that explain the variation of the NonPerforming Loans ratio. The interest rate does not represent the most important instrument used by the Central Bank of Tunisia (CBT) but rather the desired monetary aggregate.

In particular, the table shows that the monetary policy significantly contributes to the variations in RNPL from $1.37 \%$ (M2 + TMM) after 5 months to $10.098 \%$ after 10 months. Then the later contribution reaches a level close to $15.50 \%$ after 2 years. Thus, the Tunisian central bank clearly targets financial stabilization. This conclusion is well justified by the structural reforms implemented by the TCB in early 2016.The impact of economic growth on the RNPL is relatively moderate as compared to that of monetary policy, going from $2.8 \%$ after 5 months to $5.41 \%$ after 10 months. From a bank point of view, the result confirms that the capitalization of the banking sector contributes to the variation of RNPL. This contribution represents $12.07 \%$ after 2 years.

Table 5: Variance decomposition of NPL

\begin{tabular}{lcccccc}
\hline \multicolumn{7}{c}{ Variance decomposition of NPL } \\
\hline Quarter & RNPL & Loan & Cap & IPI & TMM & M2 \\
& & & & & \\
\hline 1 monthly & 100.000 & 0.0000 & 0.0000 & 0.0000 & 0.0000 & 0.0000 \\
& & & & & \\
\hline 5 monthly & 94.107 & 0.495 & 0.392 & 3.665 & 0.351 & 1.025 \\
\hline 10 monthly & 94.161 & 2.928 & 0.545 & 2.372 & 0.975 & 9.123 \\
& & & & & & \\
\hline 20 monthly & 72.437 & 2.806 & 6.531 & 1.889 & 2.361 & 13.970 \\
& & & & & & \\
\hline 24 monthly & 66.838 & 3.639 & 12.077 & 2.012 & 2.459 & \\
& & & & & & \\
\hline
\end{tabular}

\section{Conclusion}

High and progressing shares of NPL ratio exert a significant pressure on the Tunisian economies, in which the credit risk is one of the key risks for a financial stability in this economy. Several empirical surveys conclude that the Non-Performing Loans ratio, RNPL, related to various macroeconomic determinants. This study aimed at integrating macroeconomic factors of RNPL fluctuation that commonly exploited in the current literature: total credit, bank capitalization, the money supply, industrial production index as a proxy of GDP growth and the money market interest rate.

The study employed the VECM approach with forecast error variance decomposition in order to account for the crucial factor in the rise of NPL ratio in the Tunisian banking sector. Our model is able to analyze to some extend the link between macroeconomic variables and the NPLs from January 2000 to February 2018. 
Our results emphasize a negative and significant connection between IPI and the NPL ratio. This negative relationship is well justified during the revolution of 2011 since the economic activity was seriously affected, following the events that shook Tunisia. Therefore, the slowdown in economic activity has led to an increase in payments default of economic agents, which implies the rise of credit risk. Money market interest rate and the money supply are positively related to the NPL ratio. This confirms that the nature of the monetary policy adopted by the central bank of Tunisia plays an important role in the fluctuation of the NPL ratio. In the present model, the bank capitalization is negative and statistically significant with the increase of NPL ratio, implying that the bank with a low capital level has the tendency to take more risk in their credit portfolio which causes the increase of Non-Performing Loans.

The results confirm that Tunisian banks should pay more attention to several factors when offering credit (Zribi and Boujlbene, 2011), in order to improve debt conditions, consolidate banks' capital, enhance prudential rules and minimize NPLs. To this end, it is necessary to consider restructuring programs for the banking sector, especially, in matters of governance and risk management. In addition, there is a need to find solutions for a highly indebted debtor by creating, for example, a new sustainable employees.

In addition, Tunisia must create a solidarity government and make, thus, the loan and NPLs as a priority of public action. The Tunisian banking sector should also take into account the performance of the real economy when offering credit since the NPLs are higher during "bust period". Banks should also extend their macroeconomic surveillance to include prudential indicators such as credit to GDP ratio or credit to deposit ratio to ensure a proper assessment of the banking system stability.

\section{Limitation and study forward}

This study is very important since it takes into consideration the Tunisian banking sector, which is one of the pillars of the Tunisian economy. Nevertheless, this study can be enriched with other variables and other countries and in particular a comparative study between Tunisia and Morocco. These two countries are close in terms of their economic fabric, but the political aspect is different. Tunisia has gone through continuous political instability since the revolution (changes of governments), which has had an enormous influence on the country's economy.

Equally important to add in future research is the consideration of the nature of the banks' activity: commercial or Islamic banking and size: large and small banks. In this context, according to several studies, the ratio of Non-Performing Loans (NPLs) negatively affects the performance of Islamic banks. high due to better access to cheaper sources of finance. These points need to be addressed.

\section{References}

Abadi, S, Achsani, N., \& Rachmina, D. (2014). The dynamics of non-performing loan in Indonesian Banking Industry: a sensitivity analysis using VECM Approach. International Journal of Education and Research, 2(8), 124-140

Abid, 1.., Ouertani, n., \& Zouari-ghorbel, s. (2015). Les déterminants des NPLs des ménages en Tunisie, La Revue Gestion et Organisation, science direct, $\mathrm{n}^{\circ} 7$ ? pp 77-92

Adebola, S., Sulaiman, W., Yusoff, W., \& Dahalan, J. (2011). An ARDL approach to the determinants of nonperforming loans in Islamic banking system in Malaysia. Arabian Journal of Business and Management Review, 1(2), 20-30.

Akinlo, O., \& Mofoluwaso, E. (2014). Determinants of Non-Performing Loans in Nigeria. Accounting \& Taxation Journal, 6(2), 21-28

Barr, R., \& Siems, T. (1994), Predicting bank failure using DEA to quantify management quality. Federal Reserve Bank of Dallas, Financial industry Studies Working papers N ${ }^{\circ} 94$.

Beck, R., Jakubik, P., \& Piloiu, A. (2013). Non-Performing Loans: what matters in addition to the economic cycle? Working papers. European Central Bank. ISSN: $1725-2806$ (online).

BIS (2017), Resolution of Non-Performing Loans - policy options, FSI Insights on policy implementation, No.3, Financial Stability Institute, Bank of International Settlement, Working Paper. October, Brussels. 
Bouzgarrou, Béjaoui. (2013). Determinants of Tunisian banks profitability, Conference: Colloque de l'Association Tunisienne des Economistes, Hammamet - Tunisie. Volume: 9.

Buncic, D., \& Melecky, M. (2012). Macroprudential stress testing of credit risk: a practical approach for policy makers, Journal of Financial Stability. December. Volume 9.

Charalambakis, E. C., \& Garrett, I. (2019). On corporate financial distress prediction: what can we learn from private firms in a developing economy? Evidence from Greece. Review of Quantitative Finance and Accounting, 52, 467-491.

De Bock, R., \& Demyanets, A. (2012). Bank asset quality in emerging markets: determinants and spillovers, IMF Working Paper, 12.

Ekanayake, E. M. N. N., \& Azeez, A. A. (2015). Determinants of Non-Performing Loans in licensed commercial banks: evidence from Srilanka. Journal of Asian Economic and Financial. 5(6), 868882.

Enders, W. (2004). Applied econometric time series (2nd ed.). New York: Wiley

Erdoğdu, A (2015) Non-Performing Loans in Turkish banking sector and balance sheets effects. Journal of Modern Accounting and Auditing, 11(12), 677-686.

Espinoza, R., \& Prasad, A. (2010). Nonperforming loans in the GCC banking systems and their macroeconomic effects. IMF Working Paper 10/224 (Washington: International Monetary Fund).

Fawad, A., \& Taqadus, B. (2013). Explanatory power of bank specifc variables as determinants of Non-Performing Loans: evidence from Pakistan banking sector. World Applied Sciences Journal, 22, 1220-1231.

Fell, F., Moldovan, C., \& O’Brien. E. (2016). Resolving Non-Performing Loans: a role for securitisation and other financial structures? Financial Stability Review, 158 -174.

Granger, C. W. J. (1969). Investigating causal relations by Econometric Models and Cross Spectral Methods. Econometrica, 37 (3), 424-438.

Hassad, M., \& El Ghak T. (2010) Credit risk through the cycles of activity: an analysis on a panel of Tunisian banks of deposit, revue. Lebanese Management and Economics.4, 1-20.

Hue, N. T. M. (2015). Non-Performing Loans: affecting factor for the sustainability of Vietnam commercial banks, Journal of Economics and Development, 17(1), 93-106

Khemraj, T., \& Pasha, S. (2009). The determinants of Non-Performing Loans: an econometric case study of Guyana. The Caribbean Centre for Banking and Finance Bi-annual Conference on Banking and Finance, St. Augustine, Trinidad.

Messai, A., \& Jouini, F. (2013). Micro and macro determinants of Non-Performing Loans. International Journal of Economics and Financial, 3(4), 852-860.

Meh C. (2011), Bilans des banques, réduction du levier financier et mécanisme de transmission, Revue de la banque du Canada, pp. 25-36

Mimir, Y. (2013). Financial intermediaries, credit shocks and business cycles. TCMB Working Paper, No: $13 / 13,1-77$.

Nkusu, M. (2011). Nonperforming loans and macro-financial vulnerabilities in advanced economies. IMF (Working Paper no 11/161).

Ouhibi, S., Ezzeddine, S., \& Hammami, A. (2017). Non-Performing Loans and systemic risk: empirical evidence to Tunisia and Morocco. Arabian Journal of Business and Management Review, 7(2).

Ozili P. k. (2019). Non-Performing Loans and financial development: new evidence. Journal of Risk Finance.

Roland B., Petr J. and Anamaria P. (2013). Non-Performing Loans: what matters in addition to the economic cycle? Working Paper Series, NO:1515 / February 2013, European Central Bank.

Rulyasri, N., Azam Achsani, N., Mulyati, H. (2017). Effects of macroeconomic conditions on nonperforming loan in retail segments: an evidence from the Indonesian Banking. International Journal of Scientific and Research Publications, 7(10), 208-217.

Skarica, B. (2014). Determinants of Non-Performing Loans in Central and Eastern Eouropean countries. Journal of Financial.

Smaranda, C. (2017). Scoring functions and bankruptcy prediction models - case study for Romanian companies. Procedia Economics and Finance, 10, 217 - 226.

Sorge, M. (2004), Stress-testing financial systems: an overview of current methodologies. BIS Working Papers 165, Bank for International Settlements Tunisian central bank database site. 
Surjaningsih, N., G.A. Diah \& U. B. Trisnanto. (2012). The impact of fiscal policy on the output and inflation. Buletin Ekonomi Moneter dan Perbankan, Volume 14.

Tanitjob. (2019). Le Secteur bancaire Tunisien.

Available on line at : tanitjobs.com/blog/140/secteur-bancaire-enTunisie.html/\#: :text=Le\%20secteur\%20bancaire\%20tunisien\%20comprend,\%3A\%20STB\%2 C\%20BNA\%20et\%20BH.\&text=Les\%20banques\%20résidentes\%20détiennent\%20plus,l'ense mble\%20des\%20établissements\%20financiers.

Zribi, N., \& Boujlbene, Y. (2011). The factors influencing bank credit risk: The case of Tunisia. Journal of Accounting and Taxation, 3(4), 70-78, August 2011. Available online at http://www.academicjournals.org/JAT 